\title{
A deficiency of lunatic fringe is associated with cystic dilation of the rete testis
}

\author{
K L Hahn ${ }^{1,2}$, B Beres ${ }^{1,3}$, Megan J Rowton ${ }^{2}$, M K Skinner 6 , Y Chang ${ }^{1,4}$, A Rawls S $^{1,5,7}$ \\ and J Wilson-Rawls ${ }^{1,7}$ \\ ${ }^{1}$ School of Life Sciences, Arizona State University, Box 874501, Tempe, Arizona 85287-4501, USA, ${ }^{2}$ Molecular and \\ Cellular Graduate Program and ${ }^{3}$ Biology Graduate Program, Arizona State University, Tempe, Arizona 85287-4601, \\ USA, ${ }^{4}$ The Center of Infectious Disease and Vaccinology and ${ }^{5}$ The Center for Evolutionary and Functional Genomics, \\ The Biodesign Institute, Arizona State University, Tempe, Arizona, 85287-5001 USA, ${ }^{6}$ Center for Reproductive \\ Biology, School of Molecular Biosciences, Washington State University, Pullman, Washington, USA and ${ }^{7}$ Department \\ of Basic Medical Sciences, College of Medicine-Phoenix in partnership with Arizona State University, University of \\ Arizona, Phoenix, Arizona, 85004-2157 USA
}

Correspondence should be addressed to J Wilson-Rawls; Email: jeanne.wilson-rawls@asu.edu

K L Hahn is now at Yale Stem Cell Center, Yale University School of Medicine, 10 Amistad Street, Rm. 214i, New Haven, Connecticut 06509, USA

\begin{abstract}
Lunatic fringe belongs to a family of $\beta 1-3 \mathrm{~N}$-acetyltransferases that modulate the affinity of the Notch receptors for their ligands through the elongation of $\boldsymbol{O}$-fucose moieties on their extracellular domain. A role for Notch signaling in vertebrate fertility has been predicted by the intricate expression of the Notch receptors and their ligands in the oocyte and granulosa cells of the ovary and the spermatozoa and Sertoli cells of the testis. It has been demonstrated that disruption of Notch signaling by inactivation of lunatic fringe led to infertility associated with pleiotropic defects in follicle development and meiotic maturation of oocytes. Lunatic fringe null males were found to be subfertile. Here, we report that gene expression data demonstrate that fringe and Notch signaling genes are expressed in the developing testis and the intratesticular ductal tract, predicting roles for this pathway during embryonic gonadogenesis and spermatogenesis.

Spermatogenesis was not impaired in the majority of the lunatic fringe null males; however, spermatozoa were unilaterally absent in the epididymis of many mice. Histological and immunohistochemical analysis of these testes revealed the development of unilateral cystic dilation of the rete testis. Tracer dye experiments confirm a block in the connection between the rete testis and the efferent ducts. Further, the dye studies demonstrated that many lunatic fringe mutant males had partial blocks of the connection between the rete testis and the efferent ducts bilaterally.

Reproduction (2009) 137 79-93
\end{abstract}

\section{Introduction}

The Notch signaling pathway has been shown to be important for organogenesis during the embryonic development of metazoans. Activation of the Notch receptors regulates spatial identity, the formation of cellular boundaries, cell adhesion, and the switch between proliferation and differentiation (Artavanis-Tsakonis et al. 1999, Irvine 1999, Frisén \& Lendahl 2001, Koch et al. 2003). Evidence from studies in worms, flies, and mice predict a role for Notch signaling during folliculogenesis and oocyte maturation (Francis et al. 1995, Kadyk \& Kimble 1998, Deng et al. 2001, Johnson et al. 2001, Lopez-Schier \& St Johnston 2001, Hansen et al. 2004, Hahn et al. 2005). Expression of the Notch receptors, their ligands, and downstream target genes has been detected in the neonatal and adult mammalian testes (Dirami et al. 2001, van Wayenbergh et al. 2003, Hayashi et al. 2004, von Schönfeldt et al. 2004). It has been demonstrated that Notch1 and Jagged1 (Jag1) are expressed in the vasculature of the embryonic testis (Brennan et al. 2002). However, the importance of the contribution of Notch signaling to the development of the testis and later to spermatogenesis is not known.

During mammalian embryogenesis, the bipotential gonads develop as paired longitudinal ridges along the ventromedial surface of the mesonephros. Primordial germ cells (PGCs) will migrate into the bipotential gonad by embryonic day (E) 11.5 in mice and in the male will be blocked from entering meiosis (Burgoyne et al. 1988, McLaren \& Southee 1997, Swain \& Lovell-Badge 1999). Cells of the coelomic epithelium invade the presumptive 
gonad, where they coalesce with the PGCs to form the seminiferous cords by E12.5. These cells will become the Sertoli cells that support spermatogenesis. Cells from the mesonephros also migrate into the gonad and will become the Leydig and peritubular myoid cells. The seminiferous cords continue to extend toward the mesonephros, and are then referred to as testicular cords. An extension of the testicular cords will form a network of anastomosing tubules, the rete testis (Buehr et al. 1993, Merchant-Larios et al. 1993, Martineau et al. 1997, Tilmann \& Capel 1999, Morrish \& Sinclair 2002, Sadler 2003). The efferent ductules that connect to the rete testis and lead into the epididymis are derived from the mesonephric tubules, or embryonic kidney. These tubules form between regressing glomeruli, and lengthen and enlarge to form the head of the epididymis (de Kretser et al. 1982, Hinton \& Turner 1988, Ilio \& Hess 1994). At the mediastinum of the testis, the tubules of the rete testis and the mesonephric tubules that become the efferent ductules must grow toward each other and connect. The rete testis and efferent ducts perforate the tunica albuginea to form the passage from the seminiferous tubules to the epididymis in the mature testis. At puberty, the seminiferous cords become the seminiferous tubules, the site of spermatogenesis. Spermatozoa mature within the tubule supported by the Sertoli cells, and upon release into the seminiferous tubules travel to the rete testis, before entering the efferent ductules for transport to the epididymis. Notch signaling is important for the development of the kidney and genes of this pathway, including the receptors, ligands and the fringe genes, are expressed in the pronephros, mesonephros, and metanephros including the mesonephric duct and tubules and developing glomeruli (Leimeister et al. 2003, McCright et al. 2001, Wang et al. 2003, Chen \& Al-Awqati 2004, Yu et al. 2004, Piscione et al. 2004). These observations indicate that Notch may also be important for the development of the ductal tract of the testis.

The fringe proteins are Golgi-localized $\beta 1-3$ $\mathrm{N}$-acetyltransferases that modify $\mathrm{O}$-fucose moieties on the extracellular domain of the Notch receptors (Johnston et al. 1997, Bruckner et al. 2000, Moloney et al. 2000; Fig. 1). These carbohydrates modulate the affinity of the Notch receptors for their ligands (Bruckner et al. 2000, Hicks et al. 2000, Shimizu et al. 2001). There are three mammalian fringe genes, lunatic fringe $(L f n g)$,
A

Purified testis cell populations

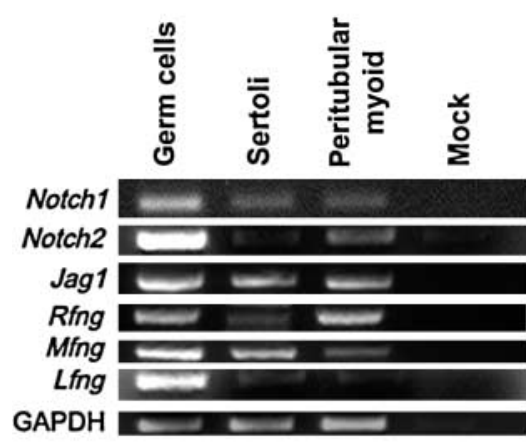

B

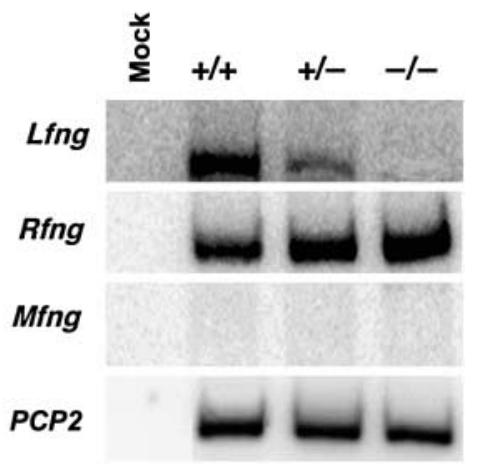

C

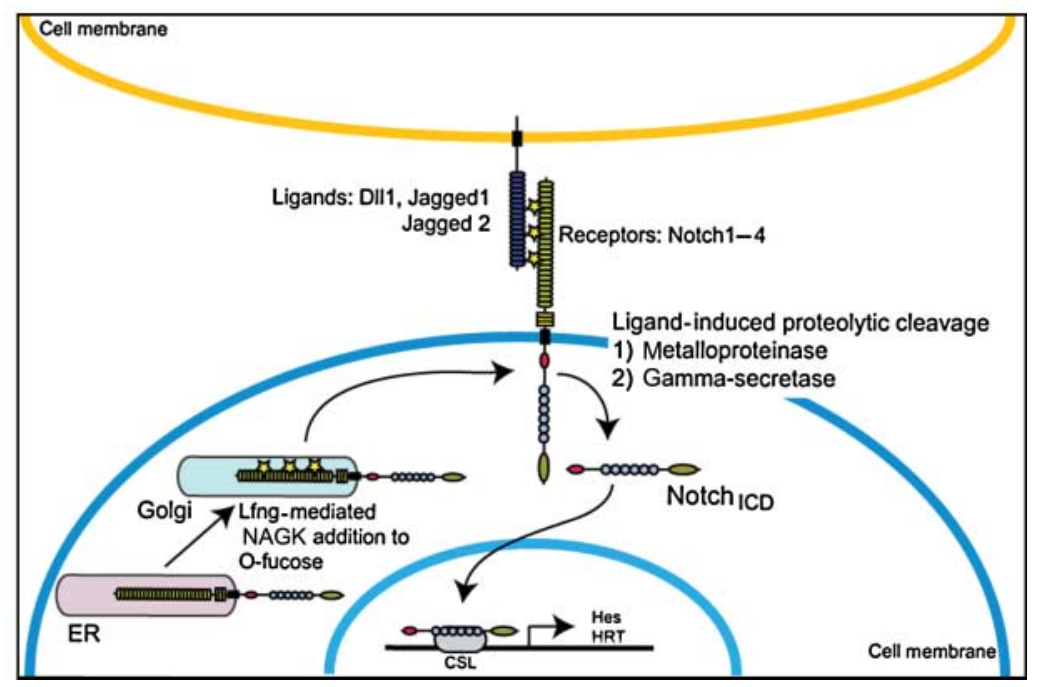

Figure 1 Fringe gene expression in the neonatal and adult testes. (A) Qualitative RT-PCR from purified testis cell populations. Purified cell populations including a mixed germ cell population, Sertoli cells, and peritubular myoid cells were harvested from $\mathrm{p} 20$ rat testis and total RNA isolated. The samples were normalized using GAPDH and genespecific primers were used to amplify transcripts. (B) SqRT-PCR from P60 total testis RNA samples. Gene-specific primers were used to detect fringe gene transcripts. All samples were normalized against $R p / 7$. Genotypes are as labeled. In each panel presented are representative data from one replicate experiment; all lanes are from a single gel. (C) Schematic of canonical Notch signaling. Notch interacts on the cell surface with its ligands, triggering proteolytic cleavage of Notch. The intracellular domain then translocates to the nucleus with a CSL transcriptional co-factor where it up-regulates the expression of downstream target genes. The fringe proteins are Golgi-localized $\mathrm{B} 1,3 \mathrm{~N}$-acetylglucosaminyltransferases that modify $\mathrm{O}$-fucose moieties added to the extracellular domain of Notch with $\mathrm{N}$-acetyl glucosamine (NAGK) during synthesis. 
radical fringe $(R f n g)$, and manic fringe (Mfng; Johnston et al. 1997). Targeted null mutations of many of the Notch receptor and ligand genes result in embryonic or perinatal lethality; however, $\sim 25 \%$ of the Lfng $^{-1-}$ mutants survive to adulthood (Evrard et al. 1998). Targeted null mutations of Lfng have segmentation defects that are similar to null mutations in Notch1 and Deltalike1 (DII1; Evrard et al. 1998, Zhang \& Gridley 1998). It was noted in mating studies done initially to assess the fertility of female $\mathrm{Lfng}^{-1-}$ mice (Hahn et al. 2005) that males demonstrated reduced fertility. In the present study, we confirmed and extended the expression data for the fringe and Notch signaling genes in the developing, neonatal, and mature testes. Based on these observations, we determined whether a lack of LFNG resulted in male reproductive tract defects that were the basis of the subfertility of the $L$ nng $^{-1-}$ males. Morphological and histological studies demonstrated that there are bilateral defects in the intratesticular ductal system in many Lfng $^{-1-}$ males, but spermatogenesis was not affected. In some of these males, there was a unilateral blind ending to the rete testis that resulted in the development of cysts.

\section{Results}

\section{Fringe genes are expressed in the developing and mature testis}

Several groups have demonstrated that Notch and its ligands are expressed in the neonatal and adult testes of mice, rats, and humans (Mori et al. 2003, Hayashi et al. 2004, von Schönfeldt et al. 2004, Sahin et al. 2005). However, nothing is known about the expression of the fringe genes in the testis, and little regarding Notch family gene expression during gonadogenesis. We datamined a microarray analysis of gene transcription from embryonic mouse testis at E11.5-E18.5 and postnatally (p) to P20 (Small et al. 2005). In this dataset, the presence of a signal of 50 is considered to be low but positive (Small et al. 2005). These data revealed a dynamic pattern of Notch and the fringe gene expression during embryogenesis and early postnatal development. Embryonically, Lfng and Rfng transcripts were detectable as early as E11.5 in the indifferent gonad and were maintained up through the neonate stage (P10) that precedes the differentiation of the testicular somatic cells. Over the same developmental timeframe, Mfng was minimally expressed. Notch1 and Notch3 were detected throughout development of the embryonic testis, while Notch2 was not detected until P3. The Notch ligand, Jag1, was detected from E11.5 to P14, but Jagged2 (Jag2) was only detected on P10. The Deltalike genes were not detected (data not shown). Transcripts from two Notch downstream target genes, Hairy enhancer of split related 1 (Hrt1) and Hairy enhancer of split 1 (Hes1), were detected from E11.5 to P14 also (Table 1).

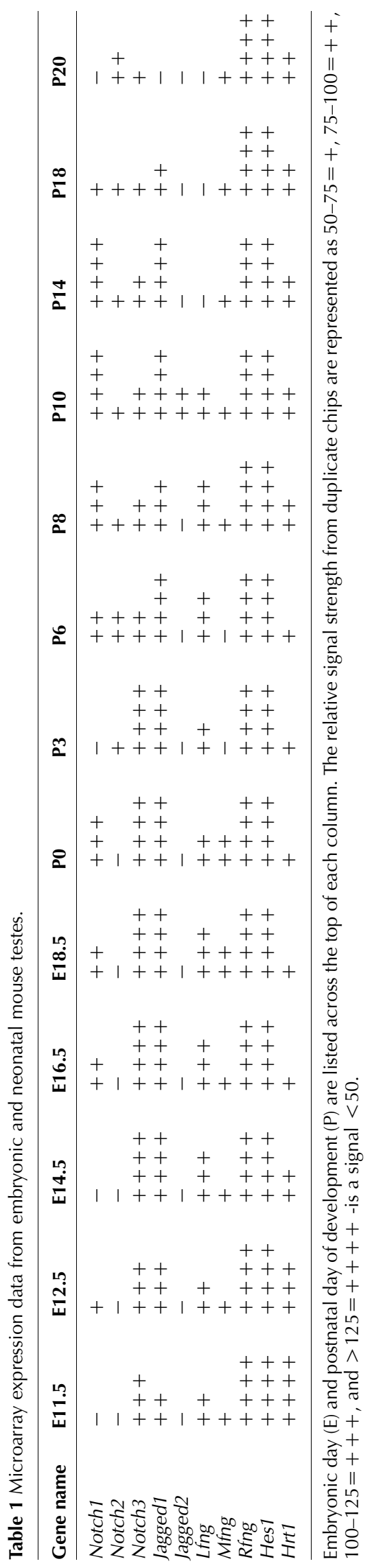

Reproduction (2009) 137 79-93 
Previous studies of Notch expression in the testis do not agree on which cells express these proteins (Mori et al. 2003, Hayashi et al. 2004, von Schönfeldt et al. 2004, Sahin et al. 2005). In order to determine the cell specificity of Notch and fringe gene expression, purified testis cell populations were used to detect transcripts. Rat P20 testes were collected and Sertoli cells, peritubular myoid cells, and a mixed germ cell population were purified. Total cellular RNA was generated and qualitative RT-PCR was done. As can be seen in Fig. 1A, Lfng, Mfng, and Rfng mRNA was detected in germ cells. Sertoli cells expressed Mfng, but Lfng and Rfng were detected weakly in them. Rfng and Mfng were detected in peritubular myoid cells, but $L$ fng is not. Notch1 and 2 were also found in germ cells, Notch1, and a weak signal for Notch2, was detected in Sertoli cells and there was a low level of expression of both of these genes in peritubular myoid cells. Jag1 was expressed in all cell types examined (Fig. 1A). Unlike the ovary, in which Lfng is expressed only in the granulosa cells (Hahn et al. 2005), all three of the fringe genes have both overlapping and distinct expression patterns in the cells of the postnatal testis. We also determined whether the fringe genes were expressed in the mature testis, using semi-quantitative RT-PCR with total testis RNA and we detected Rfng and Lfng in the P60 testis but not Mfng (Fig. 1B).

During development, the Notch receptors and ligands are expressed dynamically in the Wolffian duct, the peritubular mesenchyme around the Wolffian duct, and the developing kidney beginning at E10.0 (McCright 2001, Cheng et al. 2003, Wang et al. 2003, Piscione et al. 2004, Sharma et al. 2004, Kuure et al. 2005, Ader et al. 2006). Notch1 and Jag1 are expressed in the vasculature of the E12.5 testis (Brennan et al. 2002). Since the fringe proteins are predicted to modify the Notch receptors in the Golgi, we examined the expression pattern of $L f$ ing in the developing urogenital tract by whole-mount in situ hybridization (WISH) using a gene-specific antisense riboprobe labeled with digoxigenin and detected colorimetrically. In Lfng $^{+/+}$ embryos, we detected Lfng transcripts in the mesonephros from E12.5 to E14.5 (Fig. 2A-C, yellow arrows), consistent with the expression reported for Notch1 and -2 . In the embryonic testis, Lfng transcripts were detected in testicular cords from E12.5 to E15.5 (Fig. 2A-D, white arrows). This gene was also expressed in the mesonephric tubules between the Wolffian duct and the anterior end of the developing testis (Fig. 2A, $\mathrm{C}$ and $\mathrm{D}$ ) and this was confirmed in cryosections (Fig. 2E and F). By E15.5, expression in the mesonephros is no longer detectable and expression of $L$ fng is limited to the testicular cords and the developing epididymis (Fig. 2D). Therefore, Lfng is expressed in the developing efferent ducts, epididymis, and rete testis. We examined the expression pattern of Notch2 and Notch3 at E13.5 in the developing testis, and our data demonstrated that both
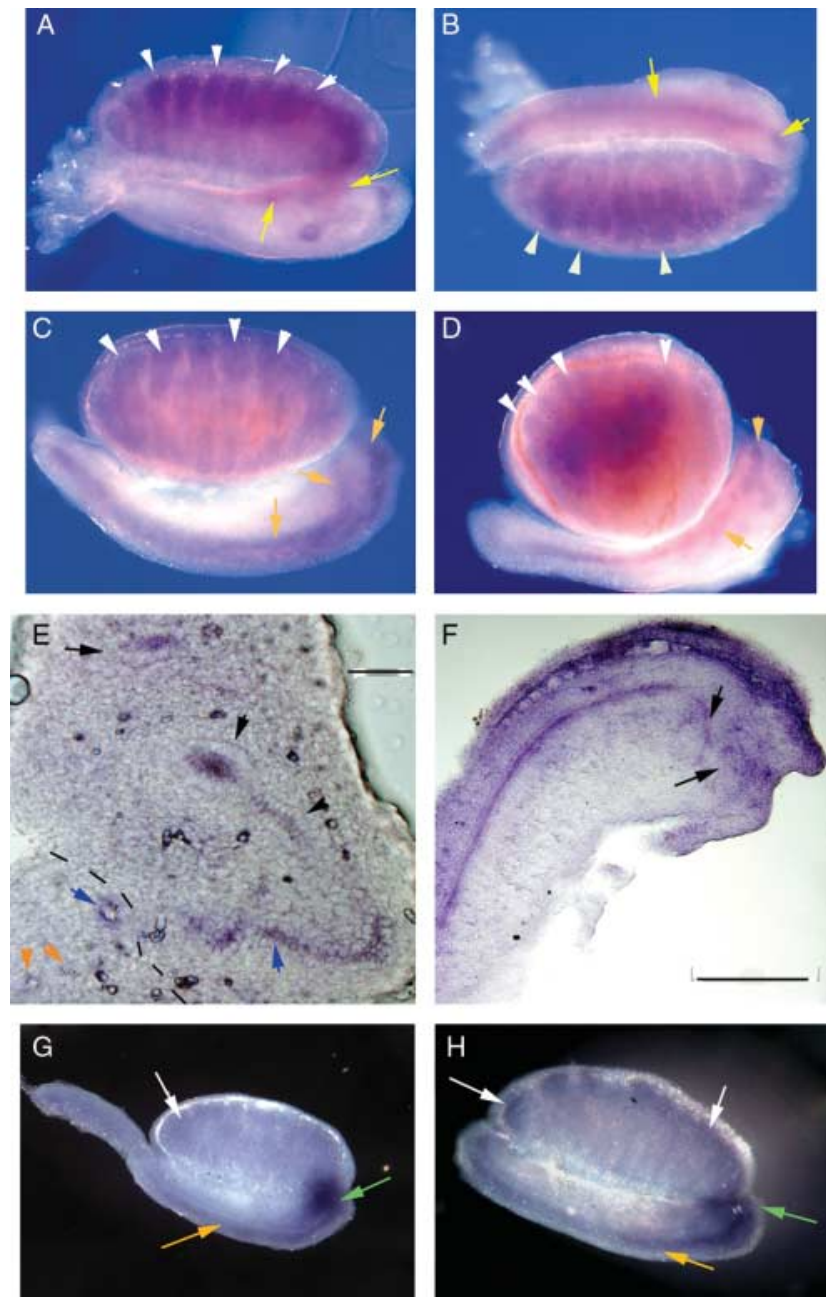

Figure 2 Lfng expression in the developing testis. (A) WISH of E13.5 mesonephros and genital ridge demonstrating Lfng transcripts in the developing testicular cords (white arrows) and the mesonephric tubules that will become the efferent ducts (yellow arrows) $60 \times$. (B) E13.5 mesonephros and genital ridge demonstrating that the mesonephric or Wolffian duct expresses Lfng (yellow arrows). Lfng expression is also visible in the testicular cords (white arrows). (C) E14.5 mesonephros and embryonic testis demonstrating continued Lfng expression in the testicular cords (white arrows), mesonephric tubules/efferent ducts, and Wolffian duct (yellow arrows). (D) E15.5 mesonephros and embryonic testis demonstrating continued Lfng expression in the testicular cords (white arrows) and in the developing efferent ducts and epididymis (yellow arrows), 60×. (E) Cryosection of E13.5 testis and mesonephros, Lfng expression is noted in the mesonephric duct (black arrow head), mesonephric tubules (blue arrows), and the rete testis (yellow arrows). Dashed line separates the testis from the mesonephros, $100 \times$.

(F) Cryosection of E13.5 testis and mesonephros demonstrating expression in the mesonephros, mesonephric ducts and developing rete testis, $200 \times$. (G) Notch3 is detected at E13.5 in the developing efferent ducts and rete testis (green arrow), weakly in testicular cords (white arrow) and mesonephros (yellow arrow), 60×. (H) Notch2 expression was detected in the E13.5 testis and mesonephros in the testicular cords (white arrows), mesonephros (yellow arrow), and developing epididymis and efferent ducts (green arrow), $60 \times$. 
are expressed in the mesonephric duct and the mesonephric tubules (Fig. 2G and H). Thus, Notch signaling genes are expressed in the testis and epididymis during development, as well as postnatally during spermatogenesis.

During development, the Notch receptors and ligands are expressed dynamically in the Wolffian duct, the peritubular mesenchyme around the Wolffian duct, and the developing kidney beginning at E10.0 (McCright et al. 2001, Cheng et al. 2003, Wang et al. 2003, Piscione et al. 2004, Sharma et al. 2004, Kuure et al. 2005, Ader et al. 2006). Notch1 and Jag1 are expressed in the vasculature of the E12.5 testis also (Brennan et al. 2002). Therefore, we determined the expression pattern of $L f n g$ in the developing urogenital tract by WISH using a genespecific antisense riboprobe labeled with digoxigenin and detected colorimetrically. In Lfng $^{+/+}$embryos, we detected $L$ fng transcripts in the mesonephros from E12.5 to E14.5 (Fig. 2A-C, yellow arrows), consistent with the expression reported for Notch1 and -2 . In the embryonic testis, Lfng transcripts were detected in testicular cords from E12.5 to E15.5 (Fig. 2A-D, white arrows). This gene was also expressed in the mesonephric tubules between the Wolffian duct and the anterior end of the developing testis (Fig. 2A, C and D) and this was confirmed in cryosections (Fig. 2E and F). By E15.5, expression in the mesonephros is no longer detectable and expression of $L f$ ng is limited to the testicular cords and the developing epididymis (Fig. 2D). Therefore, Lfng is expressed in the developing efferent ducts, epididymis, and rete testis. This was compared with the expression pattern of Notch2 and Notch3 detected at E13.5, both receptors were expressed in the mesonephric duct and the mesonephric tubules as well (Fig. 2G and H). These data confirm that Notch signaling genes are expressed during development of the testis and epididymis.

\section{Lfng null males are subfertile}

Previous studies from our group demonstrated that this Lfng $^{-1-}$ allele (Evrard et al. 1998) resulted in a loss of fertility in females (Hahn et al. 2005). A mating study was carried out to determine if male $L$ fng ${ }^{-/-}$were fertile. $L$ fng null and heterozygous control males were paired with $\mathrm{Lfng}^{+/-}$female mice. All $\mathrm{Lfng}^{+/-}$males $(n=6)$ mated within an average of 2 days, as determined by the presence of a copulatory plug. Only one $\mathrm{Lfng}^{-/-}$male $(n=4)$ mated, as determined by the presence of copulatory plugs, over the 4-month period of the study. Further, this particular $L_{f n g}{ }^{-1-}$ male demonstrated a reduced number of copulations that resulted in pregnancy, as compared with heterozygous control males ( $90 \%$ for $L \mathrm{fng}^{++-}$males and $70 \%$ for this $L \mathrm{fng}^{-1-}$ male). These observations indicate that some $\mathrm{Lfng}^{-{ }^{-}-}$males are infertile. The causes of infertility range from disruption of gametogenesis, similar to the $\mathrm{Lfng}^{-/-}$females (Hahn et al. 2005), to abnormal development of the genital tract.
In the case of the $L f n g^{-1-}$ mice, we cannot immediately rule out physical obstructions associated with fusion of the axial skeletal (Evrard et al. 1998, Hahn et al. 2005).

\section{Spermatogenesis is not defective in Lfng $^{-/-}$males}

One cause of decreased male fertility is low sperm concentration due to disrupted spermatogenesis (van der Merwe et al. 2005, Spiridonov et al. 2005). Spermatozoa were collected from the vas deferens and the cauda epididymis of $L f f^{+/+}, L^{f} g^{-/-}$, and $L_{f n g^{+/-}}$males and counted on a hemocytometer. The average sperm concentration for $\mathrm{Lfng}^{+/+}$was $6.7 \times 10^{6} \mathrm{sperm} / \mathrm{ml}$ $(n=4)$, for $L_{\text {fng }}{ }^{-\prime}-1.3 \times 10^{7} \mathrm{sperm} / \mathrm{ml}(n=13)$, and for Lfng $^{+\prime-} 2.9 \times 10^{7}$ sperm $/ \mathrm{ml} \quad(n=14)$. There was no significant difference in sperm concentration between $L_{\text {fing }}^{+/+}$and $L_{\text {fng }}^{+/-}(P=0.14)$ nor Lfng ${ }^{-/-}(P=0.3)$ or between $\mathrm{Lfng}^{+-}$and $\mathrm{Lfng}^{-/-}(P=0.06)$. Therefore, sperm concentration does not contribute to subfertility in these mice.

Since a lack of Lfng resulted in defects in meiotic maturation in oocytes (Hahn et al. 2005), the ploidy of the mature spermatozoa was determined by fluorescence-activated cell sorting (FACS). Spermatozoa were isolated from the vas deferens and epididymis of adult $L f \mathrm{fng}^{-/-}, \mathrm{Lfng}^{+/-}$, and $L \mathrm{fng}{ }^{+/+}$males, immediately fixed, stained, and FACS was done. The FACS analysis demonstrated no significant difference in ploidy, $72.03 \%$ of the $\mathrm{Lfng}^{+/+}, 88.31 \%$ of $\mathrm{Lfng}^{+/}$, and $66.75 \%$ of $\mathrm{Lfng}^{-1-}$ epididymal sperm was haploid. Further, there was no increase in aneuploidy with age in Lfng $^{-/-}$samples (Fig. 3). An increased percentage of spermatozoa with morphological defects can also lead to subfertility (van der Merwe et al. 2005, Spiridonov et al. 2005). Spermatozoa were collected, fixed immediately, and examined microscopically for morphological defects. There was no difference in the ratio of spermatozoa with morphological defects when $\mathrm{Lfng}^{-1-}$ $(n=2380)$ and Lfng $^{+/-}(n=1222)$ samples were compared. In both genotypes, $19.5 \%$ of spermatozoa were defective, and no single defect was found predominantly (data not shown).

To evaluate whether $L_{f n g}{ }^{-1-}$ spermatozoa were able to fertilize eggs and support early embryonic development, In vitro fertilization (IVF) was done using the sperm collected from the cauda epididymis and vas deferens of $L_{f n g}{ }^{+/}, L_{f n g}^{-/-}$, and $L f n g^{+/-}$males. Female $L f n g^{+/-}$ were induced to ovulate by i.p. administration of pregnant mare's serum gonadotropin (PMSG followed $48 \mathrm{~h}$ later with human chorionic gonadotropin (hCG). Oocyte cumulus complexes (OCC) were harvested from the oviduct. The OCC were mixed with capacitated sperm and fertilization was allowed to proceed for $4 \mathrm{~h}$. The eggs were washed to prevent polyspermy and placed in culture. In IVF assay, Lfng ${ }^{-1-}$ and Lfng $^{+/-}$spermatozoa fertilized $43.9 \%$ and $37.7 \%$ of the eggs, as determined by the presence of two pronuclei. Of the 

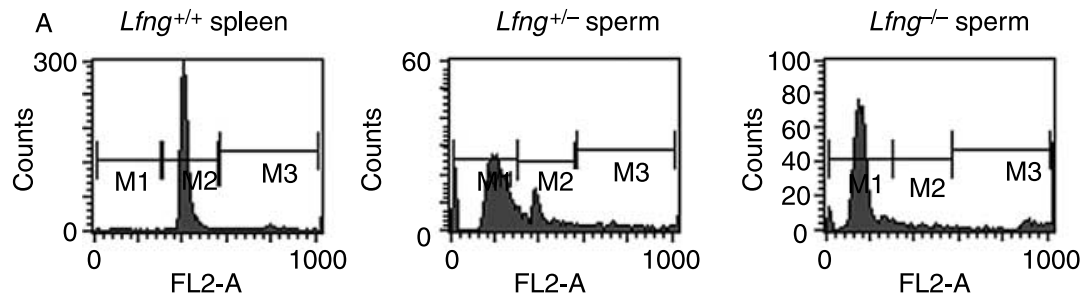

B

\begin{tabular}{cccccr}
\hline \% Gated & Spleen & Lfng $^{+/+}$P50 & Lfng $^{+-}$P50 & Lfng $^{-/-}$P50 & \multicolumn{1}{l}{ Lfng $^{-/-}$P120 } \\
\hline \hline M1 & $0.17+/-0.01$ & $72.03+/-21.25$ & $88.31+/-8.90$ & $67.75+/-25.57$ & $84.58+/-5.03$ \\
M2 & $80.19+/-7.44$ & $13.04+/-18.60$ & $0.18+/-0.20$ & $16.7+/-14.6$ & $2.37+/-1.37$ \\
M3 & $6.6+/-2.68$ & $12.08+/-11.14$ & $0.07+/-0.05$ & $12.62+/-11.53$ & $8.18+/-7.23$ \\
\hline
\end{tabular}

Figure 3 FACS Analysis of the $\mathrm{Lfng}^{-1-}$ spermatozoa. (A) Representative histograms of FACS analysis of spermatozoa. Spermatozoa were collected from the vas deferens and cauda epididymis. PI intensity (FL2-A) was used to assess nuclear DNA content. Spleen is purified spleen cells and serves as the diploid control. M1, haploid cells (200); M2, diploid G1 population (400); M3, tetraploid G2 population (800). All experiments were done with a minimum of five replicates/genotype. Gating for each sample was identical and based on the diploid spleen cells and aggregated material was excluded as much as possible. (B) Lfng ${ }^{-1-}$ spermatozoa do not demonstrate increased aneuploidy. These are aggregated percentages of the gated cells \pm s.D. for each genotype at P50 and for $\mathrm{Lfng}^{-/-}$at P120. All experiments were done with a minimum of five replicates/genotype.

eggs fertilized by spermatozoa from all three genotypes, similar numbers of embryos developed to the two-cell stage and became four- to eight-cell embryos (Table 2). The ability of spermatozoa from all three genotypes to fertilize eggs and support early embryogenesis was not significantly different. While IVF can result in fertilized eggs even if a relatively small percentage of the spermatozoa are normal, collectively, these data indicate that $\mathrm{Lfng}^{-1-}$ males had normal sperm concentrations, no increase in morphological defects, and their spermatozoa can fertilize eggs and support early embryonic development.

\section{Many Lfng $^{-/-}$males have unilateral testicular cysts}

Interestingly, while collecting spermatozoa, it was noted that some $L_{\mathrm{fng}}{ }^{-1-}$ males had a unilateral loss of sperm in the epididymis and vas deferens, suggesting a structural defect in the reproductive tract. Gross morphological examination of adult $L_{f n g^{-1}}$ male reproductive tracts demonstrated no loss of seminal vesicles, vas deferens (Fig. 4A and B, blue arrows), epididymis (Fig. 4A and $\mathrm{B}$, green arrows), or testis (Fig. 4A and $\mathrm{B}$, white arrows), nor a significant difference in size of the testes when comparing Lfng $^{-/-}$and Lfng $^{+/-}$controls (data not shown). There were Lfng $^{-/-}$ males in which one testis had a large mass discernable upon gross morphological examination $(n=3)$, (Fig. 4C, black arrow), but the contralateral testis appeared normal (Fig. 4C, white arrow).

Histological analysis showed that these testicular masses were fluid-filled cysts (Fig. 5C and D). The cysts originated in the mediastinum of the testis and pushed the seminiferous tubules to the periphery (Fig. 5C and D). Testes with very large cysts demonstrated a loss of seminiferous tubules and seminiferous tubules with thin epithelium (Fig. 5C). There are spermatozoa and large round cells in the fluid of the cysts, and it is likely that they are washed into the cyst and degenerate (Fig. 5C and G). Of the $\mathrm{Lfng}^{-/-}$males examined, $52.9 \%$ (9 out of 17) demonstrated unilateral cysts of varying severity at P50, while no cysts were detected in Lfng $^{+/-}$controls. In testes with cysts, seminiferous tubules with a normal epithelium demonstrated ongoing spermatogenesis (Fig. $5 \mathrm{H}$ ). The contralateral testes in these animals were histologically normal in appearance (Fig. 5B and F). When younger males were examined (P28), dilation of the rete testis was detected, but no large cysts (data not shown), indicating that the cysts likely increase in severity with age. Histological examination of the epididymides demonstrated normal histology, a pseudostratified epithelium with microvilli and a prominent lumen in both the mutant and controls (Fig. 6). The only notable difference was a lack of spermatozoa in the

Table 2 In vitro fertilization and early embryo development.

\begin{tabular}{lcccc}
\hline Genotype & Total eggs & Percentage of fertilized & Percentage of 2 cell & Percentage of 4-8 cell \\
\hline Lfng ${ }^{+/+}$ & 86 & $61.3(n=44)$ & $47.7(n=27)$ & $36.3(n=16)$ \\
Lfng ${ }^{+/-}$ & 255 & $43.9(n=112)$ & $46.4(n=52)$ & $33.9(n=38)$ \\
Lfng & 268 & $37.7(n=101)$ & $57.4(n=58)$ & $26.7(n=27)$ \\
\hline
\end{tabular}

Eggs are from $\mathrm{Lfng}^{+/-}$p42 female mice induced to ovulate, all healthy eggs were pooled, and used for IVF. Data are pooled from six $\mathrm{Lfng}^{-1-}$ males, seven $L_{\mathrm{fng}}{ }^{+/-}$males, and four $\mathrm{Lfng}^{+/+}$males. There was no significant difference between genotypes for advancement to the two-cell stage, nor to the four- to eight-cell stage. 

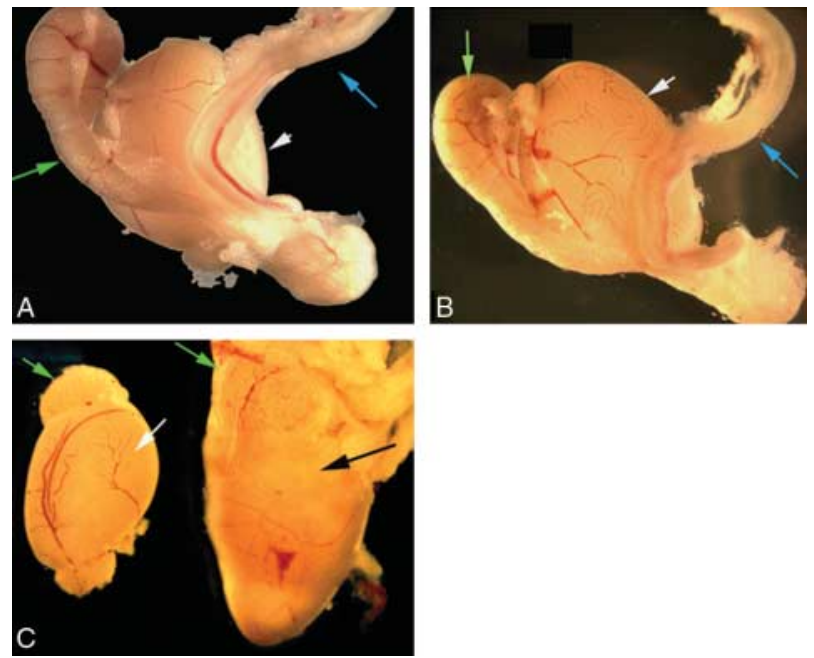

Figure 4 Gross morphological analysis of the $\mathrm{Lfng}^{-/-}$reproductive tract. Green arrows indicate epididymis, blue arrows the vas deferens, and white arrows the testis. (A) $L$ fng ${ }^{+/-}$testis, epididymis, and vas deferens. (B) $L f n g^{-l-}$ testis, epididymis, and vas deferens. (C) Comparison of contralateral testes from a P50 $\mathrm{Lfng}^{-/-}$male with unilateral cyst. Note the size difference and change in morphology due to the large mass in the testis on the right. The black arrow indicates the bulge of the mass.

epididymis of those $\mathrm{Lfng}^{-1-}$ males that had cysts (Fig. 6A and B).

Testicular cysts have been reported in mice with null mutations in Dax 1 and estrogen receptor $\alpha(\alpha-E R K O)$. Interestingly, cyst formation was associated with defects in the efferent ducts in both mutations. In Dax $1^{-1-}$ mice, a blockage of the efferent ducts is caused by the aberrant migration and proliferation of Sertoli cells up through the rete testis (Jeffs et al. 2001). The efferent ducts, rete testis, and seminiferous tubules of $\alpha$-ERKO males undergo progressive dilation due to defective fluid reabsorption by the efferent ducts (Hess et al. 1997, 2000, Lee et al. 2000). Therefore, the rete testis and efferent ducts were examined in serial histological sections from the rete testis to the epididymis in adult males ( $n=14 \mathrm{Lfng}^{+/-}$and $\mathrm{Lfng}^{-/-}$). The efferent ducts had a normal histological appearance; they were lined with an epithelium of an uneven height and cilia were present and no stenosis or dilation was detected in either null or control serial sections (Fig. 7A). The mean diameter and area of the $L_{\mathrm{fng}}{ }^{-/-}$efferent ducts was calculated using ImagePro software on every fifth serial section. The $\mathrm{Lfng}^{-1-}$ efferent ducts demonstrated no significant change in diameter or area as compared with controls (Fig. 7B).

In examining the serial sections of the rete testis and efferent ducts, we noted that in many $L^{\prime n} g^{-/-}$testes the cuboidal lining of the rete testis was abutting the tunica albuginea and there was a lack of communication between that and the efferent ducts. Conversely, in $\mathrm{Lfng}^{+/-}$males, the opening of the efferent ducts into the rete testis could be readily identified by a change in the epithelium and a break in the tunica albuginea (Fig. 8A and B). In P28 males that lacked a cyst, but demonstrated dilation and thinning of the rete testis epithelium, serial sections indicated a lack of communication with the efferent ducts. In testes with very large cysts, there was no longer a recognizable rete testis (C and $\mathrm{D}$ and $8 \mathrm{C}$ ). In order to determine whether the cysts were consistent with progressive dilation of the rete testis, immunohistochemistry $(\mathrm{IHC})$ of serial sections of testes at P28 that demonstrated dilation, but no cyst, was done to detect the presence of episialin or mucin-1 (MUC1), a marker of
A
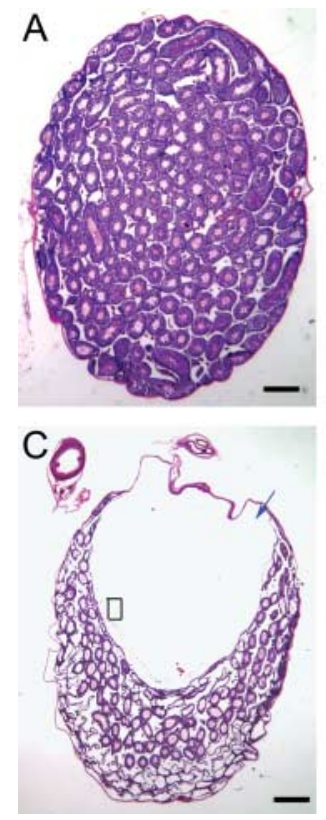
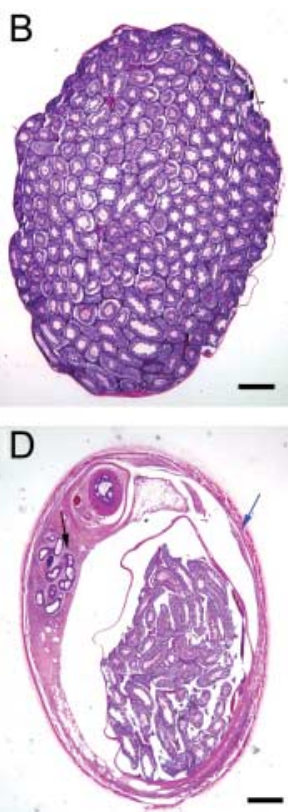
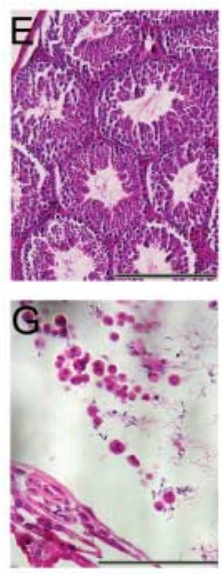
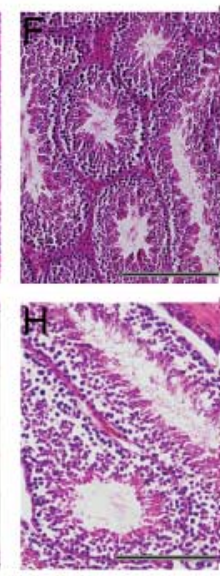

Figure 5 Histological Examination of $\mathrm{Lfng}^{-/-}$testis. Testes and epididymides of adults were harvested, fixed, paraffin embedded, sectioned to $8 \mu \mathrm{m}$, and stained with hematoxylin and eosin. (A) $\mathrm{Lfng}^{+/-}$ testis, $40 \times$. (B) $L_{\text {fng }}{ }^{-1-}$ testis normal histology, no cyst, $40 \times$. (C) Lfng $^{-/-}$testis with cyst and loss of seminiferous tubules, blue arrow denotes the acellular cyst; note the cells and spermatozoa in the cyst (black arrowheads) and the thin-walled seminiferous tubules. Black box detail is presented in panel G, $40 \times$. (D) $\mathrm{Lfng}^{-/-}$testis with cyst arising in the mediastinum (blue arrow) seminiferous, black arrow indicates the efferent ducts, $40 \times$. (E) $\mathrm{Lfng}^{+/-}$ detail of the seminiferous tubules from (A), $200 \times$. (F) $\mathrm{Lfng}^{-/-}$detail of seminiferous tubules from (B), $200 \times$. (G) Spermatozoa and round cells in the cyst from (C), $400 \times$. (H) $\mathrm{Lfng}^{-/-}$detail of seminiferous tubules from $\mathrm{D}$; note ongoing spermatogenesis, $200 \times$. These are representative photomicrographs, scale bars $=100 \mu \mathrm{m}$. 

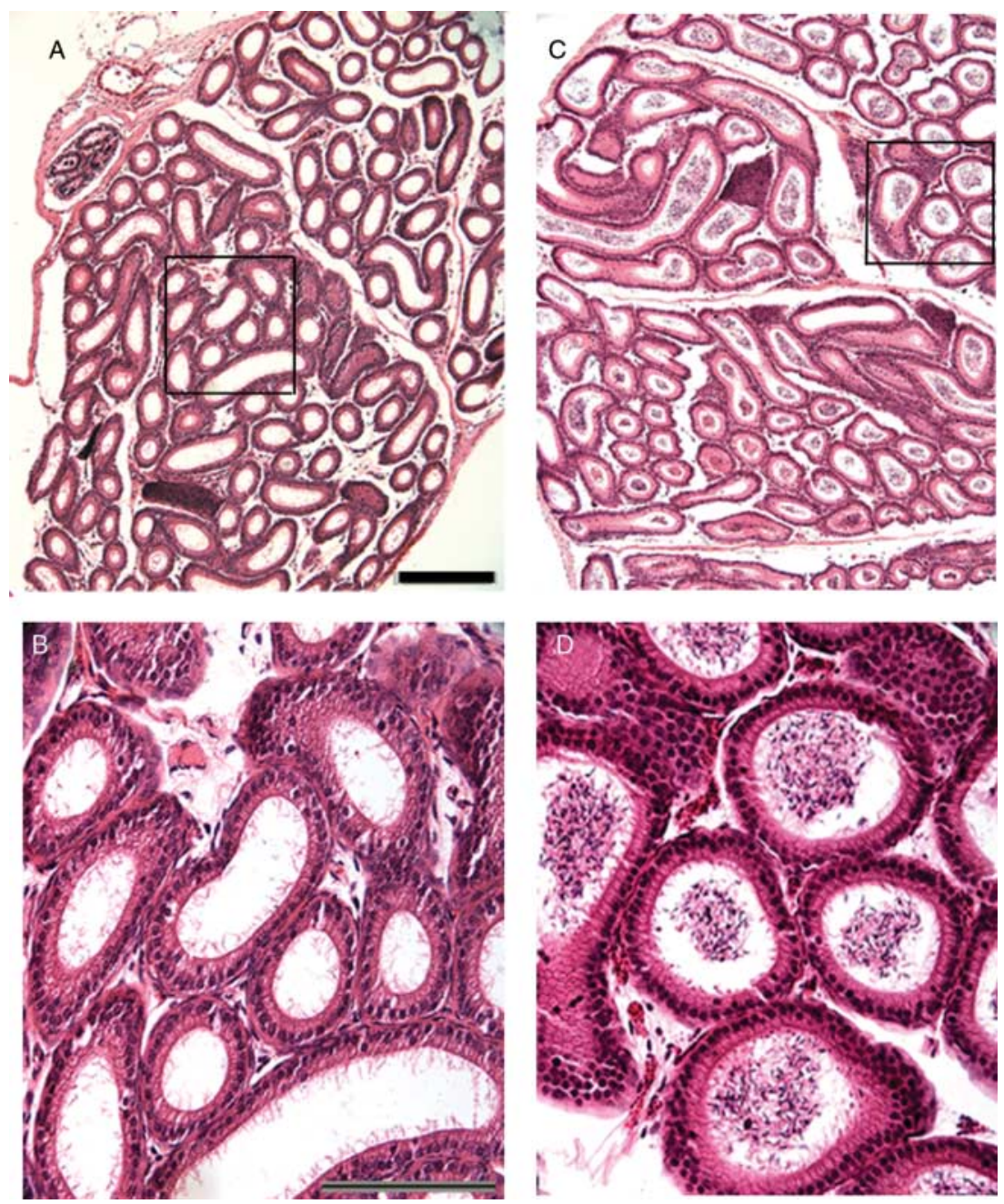

Figure 6 Histological examination of the epididymis of $\mathrm{Lfng}^{-1-}$ males. Tissues were fixed and embedded in paraffin and sectioned to $8 \mu \mathrm{m}$ then stained with hematoxylin and eosin. (A) $\mathrm{Lfng}^{-/-}$ 4150 epididymis, $100 \times$, black box detail in (B). (B) There is normal histological appearance of the epithelium and microvilli are visible, a prominent lumen consistent with control, but no spermatozoa are present, $200 \times$. (C) Lfng $^{+/-}$P50 epididymis, $100 \times$, black box detail in (D).

(D) Spermatozoa are concentrated in the lumen of the tubules, $200 \times$. the rete testis epithelium (Camassei et al. 2002). IHC detection of MUC1 in paraffin-embedded sections of testis was done colorimetrically using a polyclonal antiMUC1 antibody and slides were counterstained with hematoxylin. Epithelium lining the rete testis of $L f g^{+/-}$ expressed MUC1 (Fig. 8D), and this protein was detected in the lining of the rete testis in the $\mathrm{Lfng}^{-1-}$ males (Fig. 8E); there was no staining evident in primary antibody controls (Fig. 8F).

The formation of cysts in the rete testis of the $\mathrm{Lfng}^{-1-}$ is consistent with a lack of connection with the efferent ductules. Since the cysts were neither present bilaterally,
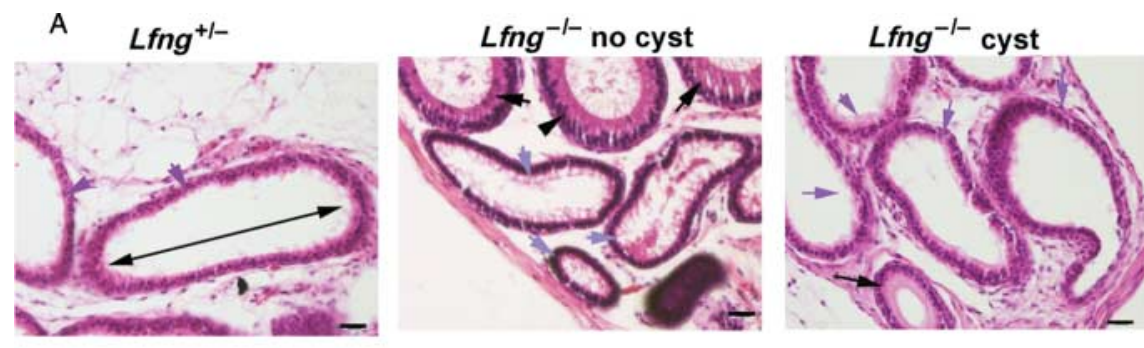

B

\begin{tabular}{lccl}
\hline & $L^{\prime f n g}{ }^{+/-}$ & $L^{\prime-1} g^{-/-}$ & $P$-value \\
Mean diameter $(\mu \mathrm{M})$ & 258.6 & 229.4 & 0.532 \\
Mean area $\left(\mu \mathrm{M}^{2}\right)$ & 2981.2 & 2899.5 & 0.958 \\
\hline
\end{tabular}

Figure 7 Analysis of the diameter and area of the efferent ducts. (A) Photomicrographs of hematoxylin- and eosin-stained sections of the efferent ducts demonstrate that there are no histological defects in the epithelium. Black arrows indicate the tubules of the epididymis and blue arrows indicate the efferent ducts, panels are as indicated above. The arrow in the lumen of the $L_{f n g}{ }^{+/-}$panel indicates the long axis for measurement of diameter. Magnification is $200 \times$ for all but $\mathrm{Lfng}^{+/-}$, which is $400 \times$, scale bars are $10 \mu \mathrm{m}$. (B) Average mean area and diameter of the efferent ducts were calculated using ImagePro and expressed as mean \pm s.D., statistics were done using one-way ANOVA. 

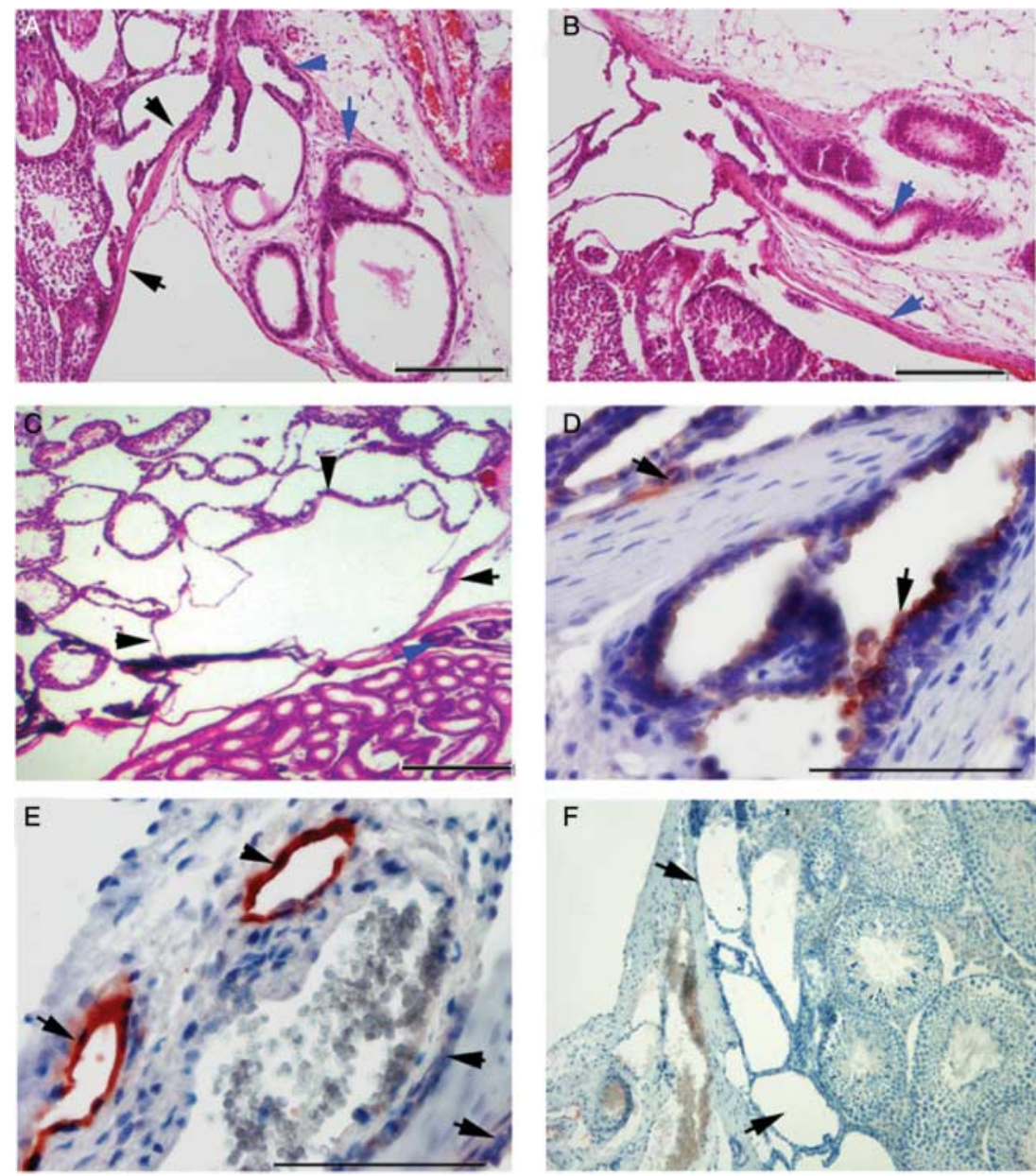

Figure 8 Histological and immunohistochemical analysis of the $L f n g^{-/-}$rete testis. (A) $L f n g^{-/-}$p28 rete testis, black arrows indicate the intact tunica albuginea (TA) with rete testis abutting it, and blue arrows indicate the proximal efferent ducts, $100 \times$. (B) Lfng $^{+/-}$p28 rete testis demonstrating communication through the TA of the rete testis and efferent ducts. Note the change in the epithelium of the continuous lumenal space. Arrows indicate the TA (black) and efferent duct (blue), $100 \times$. (C) $\mathrm{Lfng}^{-/-}$testis P50 with cyst, note the efferent ducts (blue arrow) and TA (black arrow), but the rete testis is not clearly identifiable and there are degenerating seminiferous tubules, $60 \times$. (D) $\mathrm{Lfng}^{+/-}$P28 IHC detection of mucin-1 in the epithelium of the rete testis. The slides were counterstained with hematoxylin. Arrows indicate mucin-1 positive nearly cuboidal epithelium of the rete testis, scale bars $=100 \mu \mathrm{m}, 400 \times$

magnification. (E) $\mathrm{Lfng}^{-1-}$ p28 IHC detection of mucin-1 in the epithelium lining the cystic spaces Note thinning of mucin-1 positive epithelium $400 \times$. (F) Lfng $^{-1-}$ P28 IHC detection of mucin-1, no primary antibody control, $100 \times$. nor in every male, it was possible that many $\mathrm{Lfng}^{-/-}$ males have partially blocked connections between the rete testis and efferent ducts and this may allow enough spermatozoa and fluid to move out of the testis to abrogate cyst formation. In order to determine whether this was the case, the hilum of the testis was exposed and the rete testis was slowly injected with trypan blue in Lfng $^{+/-}$and Lfng $^{-1-}$ adult males as described in Dym (1976). Post dye injection, the testis, efferent ducts, and epididymis were dissected out completely and the path of the dye was determined. All of the testes injected were blue (Fig. 9). In all $\mathrm{Lfng}^{+/-}$testes $(n=6)$, the efferent ducts were blue, consistent with the movement of dye from the rete testis. In some, the dye was detectable in the epididymis (Fig. 9A). Among the $L_{f n g}{ }^{-1-}$ mice, some testes demonstrated a complete block as determined by an absence of dye in the efferent ducts and epididymis ( $n=2$; Fig. 9B). Most of the $\mathrm{Lfng}^{-1-}$ testes had individual efferent ducts stained blue and could be followed, but other efferent ducts were not, indicating a partial block $(n=3$; Fig. 9C). There was also a testis in which all of the efferent ducts were open and dye was visible into the epididymis (Fig. 9D). We conclude that a lack of LFNG is associated with defects in the connection between the rete testis and the efferent ducts and can result in a blindended rete testis. This congenital defect can result in large cysts that involve most of the testis, resulting in the seminiferous tubules being pushed to the periphery. Based on these data, it is likely that most $L f g^{-1-}$ males have partial bilateral lack of connection between the rete testis and the efferent ducts.

\section{Discussion}

Lfng has been shown to play an essential role in the meiotic maturation of oocytes and the normal formation of the follicle. Based on our expression analysis of FRINGE genes and other members of the Notch signaling pathway, we predict a role for the Notch pathway in testis development and spermatogenesis. Here, we demonstrate that in 52.9\% of the LFNG-deficient males, unilateral testicular cysts were observed, and this was associated with an absence of sperm in the epididymis and vas deferens (Figs 4-6). Tracer dye studies demonstrated that $L f g^{-1-}$ males had reduced numbers of efferent ducts that connected properly to the rete testis and this partial block could be found bilaterally 

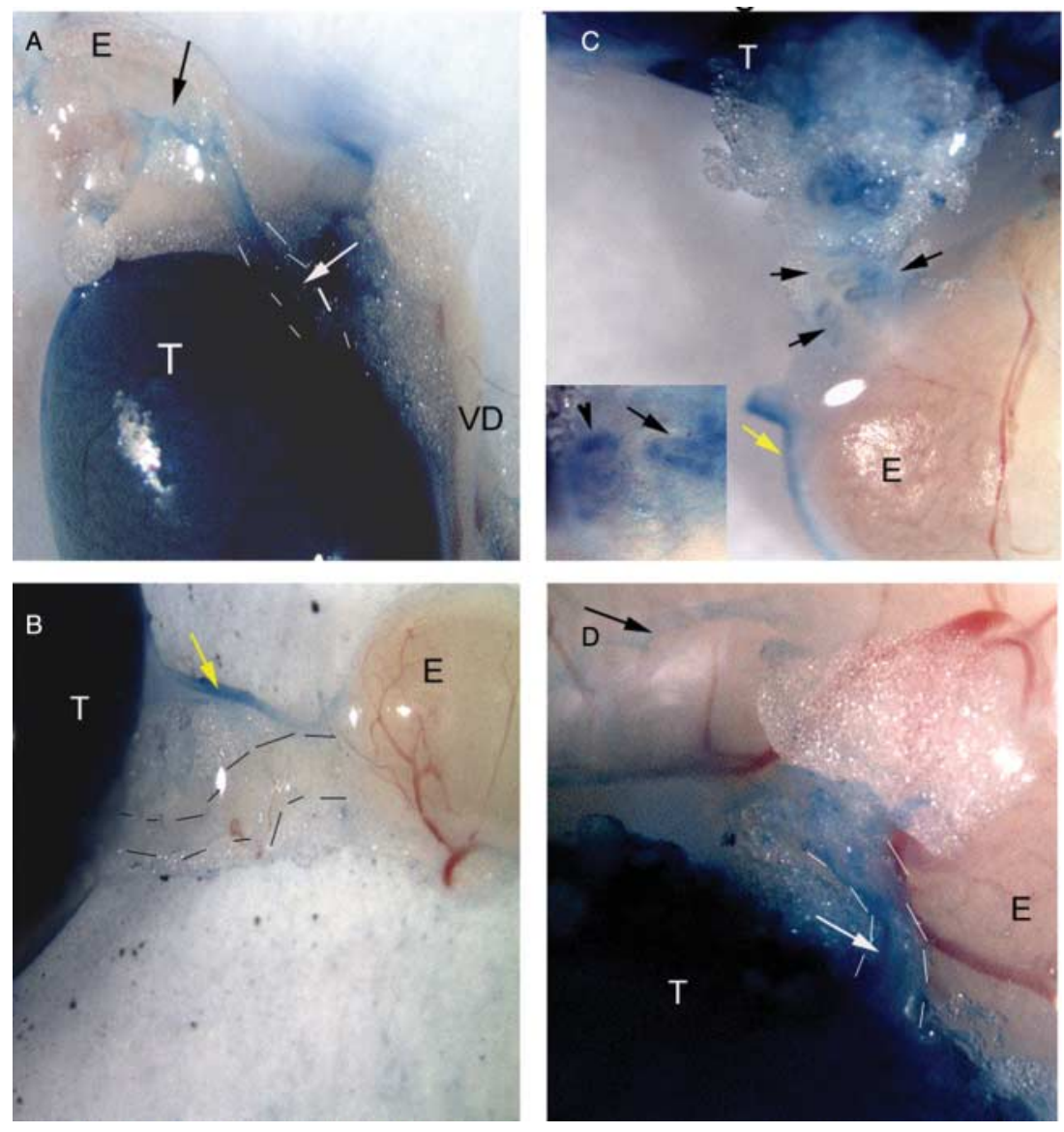

Figure 9 Tracer dye demonstrates a blind-ended rete testis. Testes were carefully dissected and injected with $0.4 \%$ trypan blue with a pulled glass needle at the mediastinum in between the vasculature. Post-injection the reproductive tract was dissected and photographed $(60 \times)$. T, testis; E, epididymis; VD, vas deferens. (A) $L_{f n g}{ }^{+/-}$, note dye in testis, efferent ducts (white arrow), and epididymis (white arrow). (B). Lfng ${ }^{-/-}$, blind rete testis, dye in testis only, some stain in connective tissue (yellow arrow). (C) Lfng $^{-/-}$, partial block, some efferent ducts had dye from the testis to the epididymis, see inset for detail. (D) $L f n g^{-/-}$no block, dye is detectable in the testis, efferent ducts, and epididymis.
(Fig. 9). The cysts found in the $L$ fng $^{-/-}$testes increase in severity with age, but are associated with neither dilated efferent ducts nor seminiferous tubules. We conclude that the cysts arise due to a congenital blind-ended rete testis. Although this defect may reduce the overall sperm concentration delivered during coitus, especially in severely affected males, it is unlikely to wholly account for the loss of fertility of the $L f g^{-1-}$ males.

The development of cysts in the rete testis has been documented in response to specific genetic lesions linked to both the loss of function and obstruction of the efferent ducts. In addition to serving as an excretory duct, the efferent ducts reabsorb fluid to concentrate spermatozoa as they move out of the testis (Ilio \& Hess 1994). This is dependent on the activity of Aquaporin1 (Aqp1) and $\mathrm{Na}+/ \mathrm{H}+$ transporter (Slc9a3; previously known as Nhe3) genes expressed in the epithelium of the efferent ducts. Inactivation of either Aqp1 or Slc9a3 leads to dilation of the rete testis (Zhou et al. 2001). The $\alpha$-ERKO males also demonstrate an increased number of blindended efferent ducts as well as dilation of the seminiferous tubules, efferent ducts, and rete testis (Eddy et al. 1996, Hess et al. 1997, Lee et al. 2000). These defects were detectable in $\alpha$-ERKO males by 10-12 weeks of age and became progressively more severe (Eddy et al. 1996, Hess et al. 1997, 2000). The expression of both Slc9a3 and Aqp1 was lost in the $\alpha$-ERKO efferent duct epithelium, predicting that defective fluid reabsorption is the cause of dilation (Eddy et al. 1996, Hess et al. 2000, Lee et al. 2000). Dilation of the rete testis has also been reported in mice deficient for Lgr4 (Mendive et al. 2006). The efferent ducts are severely hypoplastic in these animals, though they express normal levels of Aqp1 and S/c9a3. Dilation is predicted to be due to a drastically reduced surface area for fluid absorption. We propose that in $\mathrm{Lfng}^{-/-}$males a blind-ending rete testis leads to the formation of testicular cysts due to a build-up of fluid. This is consistent with the observation that the $L f_{n g}{ }^{-/-}$efferent ducts are not dilated and have neither histological nor morphological defects (Fig. 7). In mice treated with the anti-estrogen $\mathrm{ICl}$, many features of the $\alpha$-ERKO phenotype were recapitulated, however, the blind-ended efferent ductules were not, consistent with the congenital nature of this defect (Lee et al. 2000).

Notch signaling is necessary for tubulogenesis during kidney, liver, and prostate development also (McCright et al. 2001, 2002, Cheng et al. 2003, Wang et al. 2003, Grishina et al. 2005). Transgenic mice that aberrantly express the Notch ligand Jag1 throughout the Wolffian duct developed a range of renal defects that were found both 
unilaterally and bilaterally, including glomerular and tubular cysts. The most severely affected mice had unilateral renal aplasia and contralateral renal hypodysplasia with cyst formation. These defects were due to expanded temporal and spatial expressions of Jag1 that resulted in aberrant Notch activation during urogenital development (Kuure et al. 2005). Our observations are consistent with Lfng and Notch signaling being important for tubulogenesis during the formation of the efferent ductules and the rete testis in the developing gonad. WISH demonstrated that $L$ fng was expressed in the mesonephros, mesonephric duct, mesonephric tubules, the developing rete testis, and the testicular cords (Fig. 2). Notch pathway genes and Lfng are expressed in the mesonephros (McCright et al. 2001, Cheng et al. 2003, Wang et al. 2003), and our data demonstrate that they are expressed in the embryonic testis (Figs 1 and 2; Table 1). This predicts that Lfng participates in tubulogenesis in the male reproductive system. Thus, we conclude that $L f n g$ is important for the normal development of the connection between the rete testis and efferent ductules.

The phenotype of the $\mathrm{Lfng}^{-/-}$mutants varies in severity, sometimes within the same animal. Mfng and Rfng expressions overlap with that of Lfng in the developing testis and the mesonephros; this may contribute to the variation of the phenotype. Cell co-culture experiments have demonstrated that the three fringe proteins differentially modulate signaling through different Notch receptor and ligand pairs (Hicks et al. 2000, Yang et al. 2005). What emerges is a complex interaction between different Notch receptors, ligands, and fringe proteins leading to different biological outcomes. We postulate that a lack of Lfng results in an alteration in Notch signaling and this results in increased susceptibility for the development of a blindended rete testis.

Interestingly, a congenital defect in humans that consists of unilateral cystic dysplasia of the rete testis (CDRT) has been reported that shares key features of the defect we have described in $\mathrm{Lfng}^{-/-}$males. CDRT is a congenital malformation characterized by the presence of benign unilateral acellular cysts, which has been detected in children as early as birth (Camassei et al. 2002). The cysts are lined with epithelium that expresses mucin-1 and consist of multiple irregular spaces. The cysts can be very large and involve the entire testis, pushing the seminiferous tubules to the periphery. CDRT results from a congenital blind-ended rete testis and is associated with ipsilateral kidney agenesis (Leissring \& Oppenheimer 1973, Nistal et al. 1984, Glantz et al. 1995, Loo \& Yung 1995, Simoneaux et al. 1995, Zaragoza et al. 1996, Bonnet et al. 1997, Wojcik et al. 1997, Ngai et al. 1998, Robson et al. 1998, Toffulutti et al. 1999, Camassei et al. 2002, Kajo et al. 2005). CDRT is very similar to the $L$ fng-deficient phenotype we detected, implicating Notch signaling pathway genes in the development of this defect.
We propose that in $\mathrm{Lfng}^{-/-}$males, a blind-ending rete testis leads to the formation of testicular cysts due to a build-up of fluid. Dye injections into the rete testis of the $\mathrm{Lfng}^{-/-}$mice revealed a range in severity of efferent duct obstruction. The incidence of efferent duct obstruction was greater than that of rete testis cysts, suggesting that not all affected testes will progress to cysts. It is likely that falling below a threshold rate of fluid excretion from the rete testis is a contributing factor. However, the presence of rete testis cysts in the $\mathrm{Lfng}^{-1-}$ mice was invariably unilateral, suggesting additional factors are influencing the process. Unilateral congenital defects are not uncommon during testis development. In addition to CDRT, unilateral anomalies have been observed for cryptorchidism, anorchia, and vas deferens agenesis associated with cystic fibrosis transmembrane conductance regulator (CFTR) (Schindler et al. 1987, Casals et al. 1995, 2001, Alonso et al. 2001, Radpour et al. 2008). These observations indicate that the development of the male ductal tract is highly susceptible to genetic insults that result in altered signaling milieus. What these signals are and how they selectively influence the development of the testis remain to be determined.

\section{Materials and Methods}

\section{Mice}

$\mathrm{Lfng}^{-/-}$mice used in this study were originally described in Evrard et al. (1998). All animals used were bred and maintained in the vivarium at Arizona State University (ASU) on a $10 \mathrm{~h}$ light:14h darkness cycle with access to food and water and were allowed to feed ad libitum. ASU is accreditated by AALAC and all animal procedures were carried out in accordance with AALAC standards. These studies were carried out in compliance with the ASU institutional animal care and use committee under an approved research protocol.

\section{Microarray analysis}

Expression data for the Notch pathway genes in the developing testis were generated from the embryonic gonad array as described in Small et al. (2005). The array was done using Affymetrix chips and examined the relative abundance of transcripts over a developmental time course using duplicate samples of RNA. These data can be accessed at through NCBI via the Gene Expression Omnibus (GEO) data repository http://www. ncbi.nih.gov/geo/, GEO accession numbers GSE1358 and GSE1359. Supplemental data are also available through the Griswold Lab website at http://www.wsu.edu/;griswold/microarray, and include data from the statistical and clustering analyses.

\section{Mating study}

Eleven-week-old $L$ fng heterozygous and null males and eightweek old Lfng heterozygous female mice were paired. Each morning females were examined for the presence of a copulatory plug. If a plug was present, the female was removed 
and a new female introduced to the male cage. If no plug was detected after 6 days, a new female was put in the male cage. Copulatory plugs, pregnancies, and litter size were recorded and the genotype of the offspring was determined.

\section{WISH}

WISH was done on dissected CD1 embryos from E12.5-E15.5 ( $n=5 /$ timepoint). WISH on tissues were performed in the automated InsituPro (Intavis, LLC, San Marcos, CA, USA), as described previously (Anderson et al. 2006). This was followed by washing in DPBS and post-fixation in $4 \%$ para formaldehyde (PFS) in DPBS at $4{ }^{\circ} \mathrm{C}$. Antisense digoxigenin-labeled RNA probes were generated using a PCR product specific for $L$ fng. Gene-specific templates were amplified by RT-PCR from cDNA. Gene-specific primers were designed using Primer3 (Rozen \& Skaletsky 2000) and then modified by adding the T7 RNA polymerase binding site sequence (5-CTAATA CGACT CACTATAGGGAGA-3) to the 5 end of the downstream primer. A tenth of the $25 \mathrm{ml}$ PCR product was directly added to an in vitro transcription reaction with digoxigenin RNA labeling mix (Roche Applied Sciences) as described in Johnson et al. (2001). Replicates were performed on sections from at least three Lfng $^{+/+}$mice and probes were checked for specificity by WISH on embryos.

\section{Histology}

Tissues were fixed as above and sectioned to $10 \mu \mathrm{m}$. Sections were prepared by standard procedures and stained with hematoxylin and eosin. Testes from $\mathrm{Lfng}^{-1-}$ and $\mathrm{Lfng}^{+/-}$ males were examined. All photos were adjusted identically for contrast and brightness.

\section{IVF and sperm concentration and morphology}

Mice were treated via i.p. injection with 5 international units (IU) of PMSG (Calbiochem, Carlsbad, CA, USA) and $48 \mathrm{~h}$ later with 5 IU of hCG (Calbiochem). OCC were harvested from the oviduct $16 \mathrm{~h}$ later in KSOM (Specialty Media, La Jolla, CA, USA) with $10 \%$ FBS. Sperm were collected from the vas deferens and cauda epididymis in human tubal fluid (HTF; Irvine Scientific, Santa Ana, CA, USA) and capacitated for $4 \mathrm{~h}$ at $37^{\circ} \mathrm{C}$. Sperm $\left(1 \times 10^{6}\right)$ were added to each OCC sample and fertilization allowed to proceed for $2 \mathrm{~h}$ at $37^{\circ} \mathrm{C}$. Eggs were washed thrice in sperm-free $\mathrm{KSOM}$ and incubated at $37^{\circ} \mathrm{C}$. Eggs were scored as fertilized by the presence of two pronuclei and embryogenesis was scored daily. Statistical analysis was done using one-way ANOVA and likelihood ratio $\chi^{2}$ analysis.

For determination of sperm concentration, $10 \mu$ l of each sample was fixed in $4 \%$ PFA for $1 \mathrm{~min}$. and counted on a hematocytometer. For sperm morphology, $200 \mu$ sperm sample was fixed and $\sim 100$ sperm/animal was analyzed for the lack of a head or a tail, split heads, kinked tails, and presence of cytoplasmic droplet. Data were pooled and expressed as percent defective spermatozoa/genotype, statistical analysis was done using one-way ANOVA and likelihood ratio $\chi^{2}$ analysis.

\section{RT PCR}

Total testis RNA was isolated using TRIzol (Life Technologies), according to the manufacturer's directions, from three different animals/genotype. cDNA was synthesized using Superscript III (Invitrogen), according to the manufacturer's protocol. For each gene examined by semi-quantitative RT-PCR, three sets of samples comprising all three genotypes and no RT controls were amplified, using $\alpha$-[ ${ }^{32}$ P]dATP (Perkin-Elmer Life and Analytical Sciences, Boston, MA, USA). For each genespecific primer pair, the minimum number of cycles to the linear range was determined and used for all subsequent experiments. All primer sets span at least one intron. Control experiments were done using total embryo RNA. All cDNA samples were normalized using the ribosomal gene $\mathrm{Rp} / 7$ (Meyuhas \& Klein 1990) or glyceraldehyde-3-phosphate dehydrogenase (Gapdh) and quantified using a Storm 860 Phosphorlmager using ImageQuant software (Molecular Dynamics, Sunnyvale, CA, USA).

\section{FACS analysis}

The FACS analysis was done as described in Malkov et al. (1998). To obtain the sperm from p50 males, the testis, epididymis, and vas deferens were dissected and placed in $1 \mathrm{ml}$ HTF (Irvine Scientific) supplemented with 1\% BSA (Sigma). After counting, $1 \times 10^{6}$ sperm were diluted to $200 \mu \mathrm{l}$ in HTF and mixed with $200 \mu \mathrm{l}$ RNAse-digestion buffer $(2 \mathrm{mg} / \mathrm{ml}$ RNaseA in $\left.1.12 \% \quad \mathrm{Na}_{3} \mathrm{C}_{6} \mathrm{H}_{2} \mathrm{O}_{7} .2 \mathrm{H}_{2} \mathrm{O}\right)$ and $200 \mu \mathrm{l}$ staining buffer $(1000 \mathrm{mg} / \mathrm{ml}$ propidium iodide (PI; Invitrogen) in $0.2 \%$ Triton X-100, $0.1 \% \quad \mathrm{Na}_{3} \mathrm{C}_{6} \mathrm{H}_{2} \mathrm{O}_{7} .2 \mathrm{H}_{2} \mathrm{O}$ ). The spleen was harvested also and placed into $2 \%$ BSA in PBS and homogenized, then placed on ice for $5 \mathrm{~min}$. This suspension was spun down at $1500 \mathrm{~K}$ for $5 \mathrm{~min}$ at $4{ }^{\circ} \mathrm{C}$ and the supernatant was decanted. The pellet was resuspended in red blood cell lysis buffer $\left(155 \mathrm{mM} \mathrm{NH}_{4} \mathrm{Cl}, 10 \mathrm{mM} \mathrm{KHCO}\right.$, and $0.1 \mathrm{mM}$ EDTA (pH 7.4)), incubated on ice for $5 \mathrm{~min}$ and centrifuged at $5000 \mathrm{~K}$ for $15 \mathrm{~min}$ in a Sorvall at $4{ }^{\circ} \mathrm{C}$. The pellet was resuspended in $2 \% \mathrm{BSA}$ in PBS and $1 \times 10^{6}$ cells were mixed with RNaseA digestion buffer and PI staining buffer as above. The DNA content was analyzed by FACScalibur (BD Bioscience, San Jose, CA, USA). The data are presented in a histogram using splenic cells to set the diploid position, and statistics were done using one-way ANOVA.

\section{IHC}

Tissue was fixed in $4 \%$ PFA overnight at $4{ }^{\circ} \mathrm{C}$. Tissue was then paraffin embedded and sectioned to $10 \mu \mathrm{M}$. Sections were fixed to slides by heating at $80{ }^{\circ} \mathrm{C}$ for $30 \mathrm{~min}$. Slides were then cooled to room temperature, dewaxed in xylenes, and rehydrated through graded alcohols to $70 \%$ ethanol. Slides were incubated in water, followed by PBS, placed in $0.1 \mathrm{M}$ sodium citrate $(\mathrm{pH}$ 6.0) and epitope retrieval done in the microwave. The sections were cooled to room temperature, rinsed in PBS, and incubated in $3 \% \mathrm{H}_{2} \mathrm{O}_{2}$ in $60 \%$ methanol to destroy endogenous peroxidases. Mucin-1 was detected using a rabbit polyclonal anti-MUC1 antibody (Abcam, Cambridge, MA, USA) diluted 1:50 and incubated for $2 \mathrm{~h}$ at $37^{\circ} \mathrm{C}$ in a humidified chamber. 
Colorimetric detection of the protein was done using the HistostainSP kit and the diaminobenzidinetetrahydrochloride (DAB) substrate to produce a red/brown stain, according to the manufacturer's instructions (Zymed Labs, San Franscisco, CA, USA). No primary antibody controls were included in each experiment. Sections from at least three animals per genotype were examined.

\section{Measurement of diameter and area of efferent ducts}

In order to determine the diameter and area of serial sections of the efferent ducts from the rete testis to the epididymis, we used the ImagePro Plus 5.0 program (Cybernetics, Silver Spring, MD, USA). It was calibrated to a standardized stage micrometer at $10 \times$ and $20 \times$. To measure the diameter, the longest distance from one basement membrane to the opposing basement membrane was used, as described in Hess et al. (2000). To calculate area, the polygon function was used to trace the internal lumenal space. To calculate area, the following parameters within this function were set; smooth level at 9 and noise set to 5. For each set of sections, the calculations were done using every fifth section in sequence, and expressed as the mean for that animal. Statistical analysis was done using one-way ANOVA.

\section{Purified testis cell preparation}

The cell purification was done as described in Anway et al. (2004) and Muir et al. (2006). Briefly, testes were decapsulated and incubated in $0.5 \mathrm{mg} / \mathrm{ml}$ collagenase in $1 \times$ Hanks solution $\left(\mathrm{pH} \mathrm{7.4)}\right.$ at $34^{\circ} \mathrm{C}$, with shaking for $15 \mathrm{~min}$ to eliminate the interstitial cells, and then washed thrice. To separate the Sertoli and germ cells, the tubules were incubated in a mixture of enzymes $(0.1 \%$ collagenase, $0.2 \%$ hyaluronidase, $0.04 \%$ DNase I, and $0.03 \%$ trypsin inhibitor in $1 \times$ Hanks $(\mathrm{pH} 7.4)$ ) at $34{ }^{\circ} \mathrm{C}$, with shaking for $40 \mathrm{~min}$. The Sertoli cells were pelleted by centrifugation, washed in $1 \times$ Hanks, and repelleted a total of thrice. The Sertoli cells were then resuspended in $1 \times$ Hanks, subjected to hypotonic shock in a dilute Hanks solution (1:3.5; Hanks:water final dilution), and collected by centrifugation. The cells were resuspended in $1 \times$ Hanks and filtered through $53 \mu \mathrm{m}$ nylon mesh, then washed and resuspended in F12/DMEM (1:1) tissue culture medium. Cell number and purity were determined by hemocytometer and light microscopy analyses.

\section{Tracer dye studies}

The vascular pole and the rete testis of the testis were exposed in adult male mice. A $0.4 \%$ solution of trypan blue dye, which will not cross the membranes of intact cells, was injected manually using pulled glass needles as described in Dym. (1976). The dye was detectable in the testis, efferent ducts, and the epididymis of mice without defects and its presence in the seminiferous tubules of the testis was used as confirmation of successful injection in those Lfng $^{-1-}$ males with a blind rete testis. The efferent ducts were dissected from the fat pad and the entire reproductive tract removed and photographed $(n=6$ Lfng $^{+/-}$and $n=4$ Lfng $^{-/-}$).

\section{Declaration of interest}

The authors declare that there is no conflict of interest that could be perceived as prejudicing the impartiality of the research reported.

\section{Funding}

The National Science Foundation (IOB) supported JWR and AR.

\section{Acknowledgements}

The authors would like to thank Dr Ingrid Sadler-Riggleman, Sheena Howard, and members of Dr Yung Chang's laboratory for technical assistance. We would like to thank Drs Shirley Tilghman and Randy Johnson for the LFNG mutant mice.

\section{References}

Ader T, Norel R, Levoci L \& Rogler LE 2006 Transcriptional profiling implicates TGFB/BMP and Notch signaling pathways in ductular differentiation of fetal murine hepatoblasts. Mechanisms of Development 123 177-194.

Alonso MJ, Blanco A, Fernandez-Burriel M, Calleja J, Fernandez I, Sanz A, Velasco E \& Telleria J 2001 Polyvariant mutant genes: different haplotypes determining different alterations causing azoospermia. Gene Function \& Disease 1 189-193.

Anderson DM, Arredondo J, Hahn K, Valente G, Martin JF, Wilson-Rawls J \& Rawls A 2006 Mohawk is a novel homeobox gene expressed in the developing mouse embryo. Developmental Dynamics 235 792-801.

Anway MD, Wright WW, Zirkin BR, Korah N, Mort JS \& Hermo L 2004 Expression and localization of Cathepsin $\mathrm{K}$ in adult rat Sertoli cells. Biology of Reproduction 70 562-569.

Artavanis-Tsakonis S, Rand MD \& Lake RJ 1999 Notch signaling: cell fate control and signal integration in development. Science 288 770-776.

Bonnet JP, Aigrain Y \& Ferkadji L 1997 Cystic dysplasia of the testis with ipsilateral renal agenesis. A case report and review of the literature. European Journal of Pediatric Surgery 7 57-59.

Brennan J, Karl J \& Capel B 2002 Divergent vascular mechanisms downstream of Sry establish the arterial system in the $X Y$ gonad. Developmental Biology 244 418-428.

Bruckner K, Peruz L, Clausen H \& Cohen S 2000 Glycosyltransferase activity of Fringe modulates Notch-Delta interactions. Nature 406 411-415.

Buehr M, Gu S \& McLaren A 1993 Mesonephric contribution to testis differentiation in the fetal mouse. Development 117 273-281.

Burgoyne PS, Buehr M, Koopman P, Rossant J \& McLaren A 1988 Cellautonomous action of the testis-determining gene: Sertoli cells are exclusively $X Y$ in $X X-X Y$ chimaeric mouse testes. Development 102 443-450.

Camassei FD, Francalanci P, Ferro F, Capozza N \& Boldrini R 2002 Cystic dyplasia of the Rete testis: report of two cases and review of the literature. Pediatric and Developmental Pathology 5 206-210.

Casals T, Bassas L, Ruiz-Romero J, Chillón M, Giménez J, Ramos MD, Tapia G, Narváez H, Nunes V \& Estivill X 1995 Extensive analysis of 40 infertile patients with congenital absence of the vas deferens: in 50\% of cases only one CFTR allele could be detected. Human Genetics 95 205-211.

Casals T, Bassas L, Egozcue S, Ramos M, Giménez J, Segura A, Garcia F, Carrera M, Larriba S, Sarquella J et al. 2000 Heterogeneity for mutations in the CFTR gene and clinical correlations in patients with congenital absence of the vas deferens. Human Reproduction 15 1476-1483. 
Chen L \& Al-Awqati Q 2004 Segmental expression of Notch and Hairy genes in nephrogenesis. American Journal of Physiology. Renal Physiology 288 F939-F952.

Cheng HT, Miner JH, Lin M, Tansey MG, Roth K \& Kopan R 2003 Gammasecretase activity is dispensable for mesenchyme-to-epithelium transition but required for podocyte and proximal tubule formation in developing mouse kidney. Development 130 5031-5042.

Dirami G, Ravindranath N, Achi MV \& Dym M 2001 Expression of Notch pathway components in spermatogonia and Sertoli cells of neonatal mice. Journal of Andrology 22 944-952.

Deng WM, Althauser C \& Ruohola-Baker H 2001 Notch-Delta signaling induces a transition from mitotic cell cycle to endocycle in Drosophila follicle cells. Development 128 4737-4746.

Dym M 1976 The mammalian rete testis - a morphological examination. Anatomical Record 186 493-524.

Eddy EM, Washburn TF, Bunch DO, Goulding EH, Gladen BC, Lubahn DB \& Korach KS 1996 Targeted disruption of the estrogen receptor gene in male mice causes alteration of spermatogenesis and infertility. Endocrinology 137 4796-4805.

Evrard YA, Lun Y, Aulehla A, Gan L \& Johnson RL 1998 Lunatic fringe is an essential mediator of somite segmentation and patterning. Nature 394 377-381.

Francis R, Barton MK, Kimble J \& SchedI T 1995 Gld-1, a tumor suppressor gene required for oocyte development in Caenorhabditis elegans. Genetics 139 579-606.

Frisén J \& Lendahl U 2001 Oh no, Notch again!. BioEssays 23 3-7.

Glantz L, Hansen K, Caldamone A \& Madeiros LJ 1995 Cystic dysplasia of the testis. Human Pathology 24 1142-1145.

Grishina IB, Kim SY, Ferrara C, Makarenkova HP \& Walden PD 2005 BMP7 inhibits branching morphogenesis in the prostate and interferes with Notch signaling. Developmental Biology 288 334-347.

Hahn KL, Johnson J, Beres BJ, Howard S \& Wilson-Rawls J 2005 Lunatic fringe null female mice are infertile due to defects in meiotic maturation. Development 132 817-828.

Hansen D, Hubbard EJ \& Schedl T 2004 Multi-pathway control of the proliferation versus meiotic development decision in the Caenorhabditis elegans germline. Developmental Biology 268 342-357.

Hayashi T, Yamada T, Kageyama Y, Negishi T \& Kihara K 2004 Expression failure of the Notch signaling system is associated with the pathogenesis of maturation arrest in male infertility patients. Fertility and Sterility $\mathbf{8 1}$ 697-699.

Hess RA, Bunick D, Lee K-H, Bahr J, Taylor JA, Korach KS \& Lubahn DB 1997 A role for oestrogens in the male reproductive system. Nature $\mathbf{3 9 0}$ 509-512.

Hess RA, Bunick D, Lubahn DB, Zhou Q \& Bouma J 2000 Morphologic changes in efferent ductules and epididymis in estrogen receptor - a knockout mice. Journal of Andrology 21 107-121.

Hicks C, Johnston SH, diSibio G, Collazo A, Vogt TF \& Weinmaster G 2000 Fringe differentially modulates Jagged 1 and Delta1 signalling through Notch1 and Notch2. Nature Cell Biology 2 515-520.

Hinton BT \& Turner TT 1988 Is the epididymis a kidney analogue? News in Physiological Sciences 3 28-31.

Ilio KY \& Hess RA 1994 Structure and function of the ductuli efferents: a review. Microscopy Research and Technique 29 432-467.

Irvine K 1999 Fringe, Notch and making developmental boundaries. Current Opinion in Genetics \& Development 9 434-441.

Jeffs B, Meeks J, Ito M, Martinson FA, Matzuk MM, Jameson JL \& Russell LD 2001 Blockage of the rete testis and efferent ductules by ectopic Sertoli and Leydig cells causes infertility in Dax1-deficient male mice. Endocrinology 142 4486-4495.

Johnson J, Espinoza T, McGaughey RW, Rawls A \& Wilson-Rawls J 2001 Notch pathway genes are expressed in developing mammalian follicles. Mechanisms of Development 109 355-361.

Johnston SH, Rauskolb C, Wilson R, Prabhakaran B, Irvine KD \& Vogt TF 1997 A family of mammalian Fringe genes implicated in boundary determination and the Notch pathway. Development 124 2245-2254.

Kadyk LC \& Kimble J 1998 Genetic regulation of entry into meiosis in Caenorhabditis elegans. Development 125 1803-1813.

Kajo K, Matoska J, Javorka K, Machalekova K, Tomaskin R \& Kliment K 2005 Cystic dysplasia of the rete testis. Acta Pathologica, Microbiologica, et Immunologica Scandinavica 113 720-723.
Koch U, Yuan JS, Harper JA \& Guidos CJ 2003 Fine-tuning Notch1 activation by endocytosis and glycosylation. Seminars in Immunology 15 99-106.

de Kretser DM, Temple-Smith PD \& Kerr JB 1982 Anatomical and functional aspects of the male reproductive organs. In Disturbances in Male Fertility, pp 1-131. Eds K Bandhauer \& J Frick. Berlin, Heidelberg, New York: Springer-Verlag.

Kuure S, Sainio K, Vuolteenaho R, Ilves M, Wartiovaara K, Immonen T, Kvist J, Vainio S \& Sariola H 2005 Crosstalk between Jagged1 and GDNF/Ret/GFR $\alpha 1$ signalling regulates ureteric budding and branching. Mechanisms of Development 122 765-780.

Lee K-H, Hess RA, Bahr J, Lubahn DB, Taylor J \& Bunick D 2000 Estrogen receptor $\alpha$ has a functional role on the mouse rete testis and efferent ductules. Biology of Reproduction 63 1873-1880.

Leimeister C, Schumacher N \& Gessler M 2003 Expression of Notch pathway genes in the embryonic mouse metanephros suggests a role in proximal tubule development. Gene Expression Patterns 3 595-598.

Leissring JC \& Oppenheimer RO 1973 Cystic dysplasia of the testis: a unique congenital anomaly studied by microdissection. Journal of Urology 110 362-321.

Loo CKC \& Yung T 1995 Cystic dysplasia of the testis: a report of three cases and review of the literature. Pediatric Pathology \& Laboratory Medicine 15 885-893.

Lopez-Schier H \& St Johnston D 2001 Delta signaling from the germ line controls the proliferation and differentiation of the somatic follicle cells during Drosophila oogenesis. Genes and Development 15 1393-1405.

Malkov M, Fisher Y \& Don J 1998 Developmental schedule of the postnatal rat testis determined by flow cytometry. Biology of Reproduction 59 84-92.

Martineau J, Nordqvist K, Tilmann C, Lovell-Badge R \& Capel B 1997 Malespecific cell migration into the developing gonad. Current Biology 7 958-968.

McCright B, Gao X, Shen L, Lozier J, Lan Y, Maguire M, Herzlinger D, Weinmaster G \& Gridley T 2001 Defects in development of the kidney, heart and eye vasculature in mice homozygous for a hypomorphic Notch2 mutation. Development 128 491-502.

McCright B, Lozier J \& Gridley T 2002 A mouse model of Alagille syndrome: Notch 2 as a genetic modifier of Jag1 haploinsufficiency. Development 129 1075-1082.

McLaren A \& Southee D 1997 Entry of mouse embryonic germ cells into meiosis. Developmental Biology 187 107-113.

Mendive F, Laurent P, Van Schoore G, Skarnes W, Pochet R \& Vassart G 2006 Defective postnatal development of the male reproductive tract in LGR4 knockout mice. Developmental Biology $290421-434$.

Merchant-Larios H, Moreno-Mendoza N \& Buehr M 1993 The role of the mesonephros in cell differentiation and morphogenesis of the mouse fetal testis. International Journal of Developmental Biology 37 407-415.

van der Merwe FH, Kruger TF, Oehninger SC \& Lombard CJ 2005 The use of semen parameters to identify the subfertile male in the general population. Gynecologic and Obstetric Investigation 59 86-91.

Meyuhas O \& Klein A 1990 The mouse ribosomal protein L7 gene. Its primary structure and functional analysis of the promoter. Journal of Biological Chemistry 265 11465-11473.

Moloney DJ, Panin VM, Irvine KD, Haltwanger RS \& Vogt TF 2000 Fringe is a glycosyltransferase that modifies Notch. Nature 406 369-375.

Mori S, Kadokawa Y, Hoshinaga K \& Marunouchi T 2003 Sequential activation of Notch family receptors during mouse spermatogenesis. Development, Growth and Differentiation 45 7-13.

Morrish BC \& Sinclair AH 2002 Vertebrate sex determination: many means to an end. Reproduction 124 447-457.

Muir T, Sadler-Riggleman I, Stevens JD \& Skinner MK 2006 Role of the basic helix-loop-helix protein ITF2 in the hormonal regulation of Sertoli cell differentiation. Molecular Reproduction and Development 73 491-500.

Ngai RL, Yeung BK, Tsui WM \& Cheng FY 1998 Cystic dysplasia of the testis associated with ipsilateral renal agenesis and high anorectal anomalies. Journal of Pediatric Surgery 33 787-788.

Nistal M, Regadera J \& Paniagua R 1984 Cystic dysplasia of the testis. Light and electron microscopic study of three cases. Archives of Pathology \& Laboratory Medicine 108 579-583.

Piscione TD, Wu MY \& Quaggin SE 2004 Expression of Hairy/Enhancer of Split genes, Hes1 and Hes5, during murine nephron morphogenesis. Gene Expression Patterns 6 707-711. 
Radpour R, Gourabi H, Gilani MA, Dizaj S \& Vosough J 2008 A correlation between CFTR gene mutations in Iranian men with congenital absence of the vas deferens and anatomical genital phenotype. Journal of Andrology 29 35-40.

Robson WL, Thomason BMA \& Minette LJ 1998 Cystic dysplasia of the testis associated with multicystic dysplasia of the kidney. Urology 51 477-479.

Rozen S \& Skaletsky H 2000 Primer3 on the WWW for general users and for biologist programmers. Methods in Molecular Biology 132 365-386.

Sadler TW 2003 Langman's Medical Embryology, 9 edn. Philadelphia: Lippincott Williams \& Wilkins.

Sahin Z, Bayram Z, Celik-Ozenci C, Akkoyunlu G, Seval Y, Erdogru T, Ustunel I, Baykara M \& Demir R 2005 Effect of experimental varicocele on the expressions of notch 1, 2, and 3 in rat testes: an immunohistochemical study. Fertility and Sterility 83 86-93.

Schindler AM, Diaz P, Cuendet A \& Sizonenko PC 1987 Cryptorchidism: a morphological study of 670 biopsies. Helvetica Paediatrica Acta 42 145-158.

von Schönfeldt V, Wistuba J \& Schlatt S 2004 Notch-1, c-Kit, and GFRa-1 are developmentally regulated markers for premeiotic germ cells. Cytogenetic and Genome Research 105 235-239.

Sharma M, Fopma A, Brantly JG \& Vanden Heuvel GB 2004 Coexpression of Cux-I and Notch signaling pathway components during kidney development. Developmental Dynamics 231 828-838.

Shimizu K, Chiba S, Saito T, Kimano K, Takahashi T \& Hirai H 2001 Manic fringe and lunatic fringe modify different sites of the Notch2 extracellular region, resulting in different signaling modulation. Journal of Biological Chemistry 276 25753-25758.

Simoneaux SF, Atkinson GO \& Ball TI 1995 Cystic dysplasia of the testis associated with multicystic dysplastic kidney. Literature in Pediatric Radiology 25 379-380.

Small CL, Shima JE, Uzumcu M, Skinner MK \& Griswold MD 2005 Profiling gene expression during the differentiation and development of the murine embryonic gonad. Biology of Reproduction 72 492-501.

Spiridonov NA, Wong L, Zerfas PM, Starost MF, Pack SD, Paweletz CP \& Johnson GR 2005 Identification and characterization of SSTK, a serine/threonine protein kinase essential for male fertility. Molecular and Cellular Biology 25 4250-4261.

Swain A \& Lovell-Badge R 1999 Mammalian sex determination: a molecular drama. Genes and Development 13 755-767.
Tilmann C \& Capel B 1999 Mesonephric cell migration induces testis cord formation and Sertoli cell differentiation in the mammalian gonad. Development 126 2883-2890.

Toffulutti T, Gamba PG, Cecchetto G, Talenti E \& Tchaprassian Z 1999 Testicular cystic dysplasia: evaluation of 3 new cases treated without surgery. Journal of Urology 162 2146-2148.

Wang P, Pereira FA, Beasley D \& Zheng H 2003 Presenilins are required for the formation of comma- and $S$-shaped bodies during nephrogenesis. Development 130 5019-5029.

Van Wayenbergh R, Taelman V, Pichon B, Fischer A, Kricha S, Gessler M, Christophe D \& Bellefroid EJ 2003 Identification of BOIP, a novel cDNA highly expressed during spermatogenesis that encodes a protein interacting with the orange domain of the hairy-related transcription factor HRT1/Hey1 in Xenopus and mouse. Developmental Dynamics $228716-725$.

Wojcik LJ, Hansen K, Diamond DA, Koyle M, Koff S, Coplen DE \& Caldamone AA 1997 Cystic dysplasia of the rete testis: a benign congenital lesion associated with ipsilateral urological anomalies. Journal of Urology 158 600-604.

Yang L-T, Nichols JT, Yao C, Manilay JO, Robey EA \& Weinmaster G 2005 Fringe glycosyltransferases differentially modulate Notch1 proteolysis induced by Delta1 and Jagged1. Molecular Biology of the Cell 16 927-942.

Yu J, McMohan AP \& Valerius MT 2004 Recent genetic studies of mouse kidney development. Current Opinion in Genetics \& Development 14 550-557.

Zaragoza MR, buckler LB \& Parikh MJ 1996 Cystic dysplasia of the testis: an unusual cause of a pediatric scrotal mass. Urology 47 244-247.

Zhang NA \& Gridley T 1998 Defects in somite formation in lunatic fringe deficient mice. Nature 394 374-377.

Zhou Q, Clarke L, Nie R, Carnes K, Lai L-W, Lien Y-HH, Verkman A, Lubahn D, Fisher JS, Katzenellenbogen BS et al. 2001 Estrogen action and male fertility: roles of the sodium/hydrogen exchanger-3 and fluid reabsorption in reproductive tract function. PNAS 98 14132-14137.

Received 15 May 2008

First decision 2 July 2008

Accepted 17 September 2008 